\title{
1. Teaching entrepreneurship as a method that requires practice
}

Entrepreneurship is neither science nor art. It is a practice. (Peter Drucker)

The message of our book is quite simple. We want to advance entrepreneurship education for all types of students using an action-based method rooted in a specific set of practices. From our extensive experience training a global cadre of entrepreneurship educators (four-year college professors, community college professors, and adjuncts), we have observed that the mindset of most educators is discipline specific and rooted in process models. Though the entrepreneurship process orientation is the most common approach seen in entrepreneurship education today, we posit that it is neither the most realistic nor the most effective approach for the current environment, which is characterized by increasingly high levels of uncertainty.

While entrepreneurship education has not significantly changed in at least two decades, the global emphasis on the relevance and potential impacts of entrepreneurship has dramatically increased and is cited as a potent economic force (Kuratko, 2005). As educators we are lagging, and our role in the world cannot be undervalued. The late Jeff Timmons ${ }^{1}$ said that entrepreneurship is "not just about new company, capital and job formation, nor innovation, nor creativity, nor breakthroughs. It is also about fostering an ingenious human spirit and improving humankind."

At the same time as we have seen this change in the phenomenon of entrepreneurship around the world, business education in general has come under scrutiny (Trank and Rynes, 2003; Mintzberg, 2004; Bennis and O'Toole, 2005; Datar, Garvin, and Cullen, 2010), and content is becoming a commodity. Entrepreneurship education is not without its share of criticism given the dearth of research on its impact (Kuratko, 2005). As a result our role, our classrooms, and our teaching approaches are being challenged - and rightfully so. Now more than ever our role as educator is to unleash the entrepreneurial spirit of our students, cultivate a mindset of practice, and build environments in which practice can occur. In turn our students can lead more entrepreneurial lives because of their newly found bias for action, appreciation for learning through action, and 
comfort with ambiguity. Yet the big question remains: How should entrepreneurship be learned?

As we lag a bit in education legitimacy, entrepreneurship's academic legitimacy continues to grow because of scholars heeding calls to action with respect to research domains and important questions (Brush et al., 2003; Kuratko, 2005). Membership in the entrepreneurship division of the Academy of Management now tops 2400 - one of the largest divisions in the academy. The number of abstracts submitted to the Babson College Entrepreneurship Research conference now exceeds 750 . There are 71 refereed journals devoted to entrepreneurship, over 100 U.S. university-based centers, and more than 400 endowed chairs. We are also fortunate to have largely buried the "Can entrepreneurship be taught?" debate, even though this continues to be a favorite question posed by popular press journalists. Legendary educator Peter Drucker (1985) said "Entrepreneurship is not magic, it is not mysterious and it has nothing to do with genes. It is a discipline. And, like any discipline, it can be learned."

Since the late 1980s entrepreneurship education has exploded across the globe. All AACSB-accredited schools are teaching entrepreneurship at some level (Katz, 2003). In the United States alone there are 2200 courses being offered at 1600 colleges and universities (Katz, 2003). It is one of the fastest growing subjects among undergraduate institutions (Myrah and Currie, 2006) and a primary source of growth for MBA programs (MBA Roundtable, 2012). China's premier, Li Kequiang, has promised unprecedented support for entrepreneurship education (Bastin, 2014). The Malaysian government launched the Higher Education Entrepreneurship Development Policy in 2010 (http:// www.mohe.gov.my/portal/en/pelajar/program-keusahawanan.html) with a goal of graduating college students with a greater ability to think and act entrepreneurially as a "catalyst for the achievement of economic transformation of the country from a middle to high income economy." Banco de Chile is funding a five-year program to train Chilean educators in Babson's approach to entrepreneurship. And Babson's Symposium for Entrepreneurship Educators indirectly touches over 7000 students per year by training a global cadre of faculty. More locally the private sector is jumping on board. For example, Goldman Sachs has funded and supported a program for the growth of 10000 Small Businesses through entrepreneurship education delivered to business owners through community colleges across the United States and in the UK, as well as 10000 Women, which has actually reached its 10000 th participant. Large foundations such as Kauffman and Coleman support education initiatives on multiple levels, and the Network for Teaching Entrepreneurship (NFTE) 
is making significant impact with its initiatives at the primary and secondary levels of education.

Entrepreneurship education is exploding, and new approaches are needed not only to keep up with demand but also to keep up with the changing nature of entrepreneurship education - which is precisely the reason why we have written Teaching Entrepreneurship! This book approaches teaching entrepreneurship from a new practice-based perspective. We are not advocating a particular course or curriculum; rather, we are advancing the notion that entrepreneurship is a method composed of a portfolio of practices. And these practices can happen in any course, on any campus, with any student! To better understand why we embarked on the journey of this book, it is important to have a historical perspective of the entrepreneurship field from both a research and a teaching perspective. The two are highly intertwined, and it is not prudent to discuss research without teaching and vice versa; therefore our historical discussion is followed by a consideration of the conundrum of theory versus practice in education, a point of particular concern for us given the perceived practicality of the field of entrepreneurship. We then introduce entrepreneurship as a method, discuss the role of practice in theory, and introduce the five practices of entrepreneurship education highlighted throughout the book.

\section{THE EVOLUTION OF ENTREPRENEURSHIP EDUCATION: FROM INDIVIDUAL TO PROCESS TO METHOD}

The role of the entrepreneur in economic theory dates back to the early 1940s, yet until 1970 very few business schools offered courses in entrepreneurship (Vesper and Gartner, 1997). The 1970s were a time of transition for small business ownership in the U.S. overall. The number of small businesses had been declining across the country since the industrial revolution. However, in 1972 the decrease leveled off, and for the following decades the numbers of small businesses again began rising (Greene, 1993). Many reasons have been proposed for the change, some economic, some sociological. One perspective, proposed by Vesper and Gartner (1997), speculates that technological advances, such as the personal computer, created new markets and an array of opportunities emerged. The pace of change and the ease of entry created a wave of entrepreneurship that has yet to subside. Parallel to these structural changes, in the early 1970s "connotations of the term 'entrepreneur' began to shift from notions of greed, exploitation, selfishness, and disloyalty to creativity, job creation, profitability, innovativeness, and generosity" (Vesper and Gartner, 1997, 
p.406). Entrepreneurs began to be recognized not only as a driving force of the economy, but also as very positive and contributing members of society. These changes have continued until now. In the present day, according to the Global Entrepreneurship Monitor, high status for being an entrepreneur is perceived among 72 percent of entrepreneurs practicing in 69 economies, and 68 percent believe entrepreneurship is a good career choice (Xavier et al., 2012).

Early research efforts focused on the traits of entrepreneurs. Researchers attempted to identify a certain set of characteristics that differentiated entrepreneurs from non-entrepreneurs (e.g. McClelland, 1965; Collins and Moore, 1970; DeCarlo and Lyons, 1979; Brockhaus, 1980; Cooper and Dunkelberg, 1981). Brockhaus and Horwitz (1986) reviewed the trait literature and concluded that there are four major personality traits of entrepreneurs: need for achievement, internal locus of control, high risk-taking propensity, and tolerance for ambiguity. Since this time, however, there has been very little consensus in the trait literature or further scientific evidence that the four traits are from either nature or nurture. These early research efforts were present in most entrepreneurship textbooks, with opening chapters discussing "who" the entrepreneur is and what kind of personality profile "he" possesses. Many years ago Low and MacMillan (1988) argued that any attempt to profile the typical entrepreneur was inherently futile, yet the research, to our dismay, continues. Miner (1996) proposed four psychological personality patterns of entrepreneurs: personal advisors, empathetic super-salespeople, real managers, and expert idea generators. Also, most recently, Shane posited the role and presence of an entrepreneurial gene (Mount, 2010), taking the nature-versusnurture discussion to new extremes. Fisher and Koch (2008), in their book Born Not Made, bring us backwards arguing there is a personality profile, but their profile is heavily influenced by risk-taking propensity. Why do we still believe that all entrepreneurs are extreme risk takers?

In response to the traits approach Gartner (1988) argued for a behavioral approach to the study of entrepreneurship. For Gartner, entrepreneurship is ultimately about the creation of organizations (new venture creation), where many influences interact in the emergence process. The entrepreneur is only a part of the process; therefore, the activities undertaken by the entrepreneur in the context of new venture creation should be examined. As a result, research should focus on what the entrepreneur does - not who he or she is. Yet behaviors across samples of entrepreneurs are very idiosyncratic, so it became difficult to generalize this research for teaching purposes. To prove this point, a study comparing textbook content to the behaviors of nascent entrepreneurs concluded that there was very little overlap (Edelman et al., 2008). But researcher calls to 
move away from traits to behaviors did ultimately move entrepreneurship education away from the focus on one type of individual to a view of entrepreneurship as a process (Bygrave and Hofer, 1991). ${ }^{2}$ As the process approach made its way into entrepreneurship classrooms, entrepreneurship became a linear activity of identifying an opportunity, developing the concept, understanding resource requirements, acquiring resources, developing a business plan, implementing the plan, managing the venture, and exit (Morris, 1998). In our opinion, entrepreneurship became just another version of management - a process of leading, controlling, planning, and evaluating, with the difference being its application to new organizations. Today the process orientation has a stronghold in entrepreneurship education. We conducted a review of 45 entrepreneurship textbooks currently on the market, and approximately 80 percent emphasize the process of entrepreneurship. Process topics included opportunity evaluation, business planning, marketing planning, resource acquisition, managing the business, and exit.

The entrepreneurship-as-process approach was heavily influenced by the proliferation of strategy scholars entering the field, and a debate between strategic management and entrepreneurship scholars ensued (Shane and Venkataraman, 2000; Hitt et al., 2001a, 2001b; Zahra and Dess, 2001; Meyer et al., 2002). Both fields felt the need to create distinction, and for entrepreneurship the space for this distinction was created by Venkataraman (1997). He called for researchers and educators in entrepreneurship to confront the question "What is the distinctive contribution of our field to a broader understanding of business enterprise?" He continued, "To the extent that our answer to this question is unclear, delayed and overlaps with other sub-fields, our legitimacy and our very survival in the world of business research and education is seriously threatened" (Venkataraman, 1997, p. 119). Shane and Venkataraman's (2000) seminal article introduced a definition of entrepreneurship that was distinctive: "the identification, evaluation, and exploitation of opportunities" (Shane, 2012, p. 12). This definition has become the most used and cited definition in the field (Aldrich and Cliff, 2003).

Acceptance of this scholarly pursuit by academicians led to the reemergence of studying individual entrepreneurs (but, thankfully, not from a traits perspective). Instead, the entrepreneurial cognition approach to studying entrepreneurship gained and continues to gain traction. Rather than distinguishing entrepreneurs based on personality traits, cognition researchers were uncovering patterns in how entrepreneurs think and began hypothesizing that specific ways of thinking were sources of competitive advantage and individual differentiation (Mitchell et al., 2000, 2002). Entrepreneurial cognition is defined as "the knowledge structures 
that people use to make assessments, judgments, or decisions involving opportunity evaluation, venture creation, and growth" (Mitchell et al., 2002, p. 97).

While most of the cognition work focused on why individuals make decisions pertaining to entrepreneurial action and related such decision making to deeply held knowledge structures and beliefs (Krueger, 2007), another stream of cognition-based research emerged that sought to address barriers to entrepreneurship - or the how part of entrepreneurship that related to the starting point for persons wishing to undertake entrepreneurial endeavors. To this point, largely missing from the discussion was "consideration of the origin of initial resource strengths, and how they contribute to, or determine, value-creating activities" (Brush et al., 2001). In other words, the question was no longer can an individual be an entrepreneur but rather how an individual can become entrepreneurial, create opportunities, and act on them. The work of Saras Sarasvathy (2001, 2003, 2008), a student of Nobel laureate Herbert Simon, introduced the field to a controversial new theory - effectuation.

Sarasvathy's dissertation research incorporated think-aloud, verbal protocols with 45 expert entrepreneurs. The experimental methodology required subjects to "think aloud" as they made decisions and solved a set of ten typical problems that occur in a start-up (Sarasvathy, 2008, p. 23). ${ }^{3}$ Her resulting theory of effectuation emerged in contrast to its inverse, causation.

Causal models begin with an effect to be created. They seek either to select between means to achieve those effects or to create new means to achieve preselected ends. Effectual models, in contrast, begin with given means and seek to create new ends using non-predictive strategies. In addition to altering conventional relationships between means and ends and between prediction and control, effectuation rearranges many other traditional relationships such as those between organism and environment, parts and whole, subjective and objective, individual and social, and so on. In particular, it makes these relationships a matter of design rather than one of decision. (Sarasvathy, 2008, p. 16)

Understanding how entrepreneurs view the world and how they learn, the entrepreneurial mindset suddenly became important - really important! Sarasvathy (2008) empirically discovered that effectual entrepreneurs see the world as open to a host of different possibilities, fabricate as well as recognize new opportunities, make rather than find markets, accept and leverage failure, and interact with a variety of stakeholders - all for the purposes of creating the future rather than trying to predict the future (Schlesinger et al., 2012). 
The discovery of patterns in how entrepreneurs think (Sarasvathy, 2008) combined with additional research from Babson (Costello et al., 2011; Greenberg et al., 2011; Neck and Greene, 2011; Noyes and Brush, 2012; Schlesinger et al., 2012) encouraged us to think about moving entrepreneurship education to the next level. Building off effectuation theory (Sarasvathy, 2008), we believe that entrepreneurship can no longer be taught as a process but rather must be taught as a method (Venkataraman et al., 2012). The method of entrepreneurship requires the development of a set of practices. Through these practices we can help students think more entrepreneurially, which in turn can develop students who can act more entrepreneurially.

As you can see from this historical view, the method is not devoid of theory. As a matter of fact, theory in our view plays a stronger role in entrepreneurship education than ever before. Theories related to entrepreneurial cognition are just our jumping-off platform for establishing the need for entrepreneurship as a method. The practices that constitute the method are steeply entrenched in theory from a multitude of disciplines that we will discuss throughout the book.

\section{THE THEORY VERSUS PRACTICE CONUNDRUM}

If we look at the history of education, theory actually ruled first. Indeed, practice has been getting a bad rap since Plato's Theory of Forms. Brockbank and McGill (2007) provide a helpful description of Plato's early dualistic approach between the intellectual and aesthetic work of the ruling class and the others, the ruled, who engage in manual work. The manual workers were decidedly seen as lesser. This particular philosophical emphasis, grounded largely in Plato and Aristotle, also, however, presents us with the beginning of the theory-practice conflict. Both Plato and Aristotle "championed the primacy of the intellect over practice" and set the tone, a theme picked up later in the work of Descartes. While this model is still a significant influence on our traditional model of higher education, upon reflection, the path was not as straight and clear as sometimes reported. One crack in the road is Aristotle's contribution about the importance of learning by doing, with his example centering on the learning of virtue (Brockbank and McGill, 2007, p. 19). In fact, while this either/or approach has since been labeled as a "category mistake" (Ryle, 1983 in Brockbank and McGill, 2007, p. 19) that privileges the "mind domain" over the domain of the body, the mistake is actually attributed to an early philosophical dilemma concerning how to think about the soul. Of most concern for us is that "This polarization and differentiation of 
mind and matter has remained intact and lives today in the persistence of dualism in academic life, with skills, 'knowing how,' practice and affect being undervalued, while cognition, 'knowing that' and impersonal modes of communication are championed through the academy" (Ryle, 1967 in Brockbank and McGill, 2007, p. 20).

While the dominance of the importance of theory is strongly supported by the early philosophers, the critical importance of practice has emerged more strongly over the last half-century, largely driven by the work of Pierre Bourdieu, who called out Plato on this very subject, claiming that Plato had tipped the balance by negatively describing the logic of practice (Bourdieu, [1980] 1990):

But the most formidable barrier to the construction of an adequate science of practice no doubt lies in the fact that the solidarity that binds scientists to their science (and to the social privilege which makes it possible and which it justified or procures) predisposes them to profess the superiority of their knowledge, often won through enormous effort, against common sense, and even find in that superiority a justification for their privilege, rather than to produce a scientific knowledge of the practical mode of knowledge and of the limits that scientific knowledge owes to the fact that it is based on a privilege. (Bourdieu, [1980] 1990, p. 28)

There is a continuing and growing quandary in entrepreneurship education: What are the role of theory and the role of practice in the entrepreneurship classroom? The battle for power and position between theory and practice is one that has been oft discussed in teaching discussions and publications. Wren et al. (2007) updated research conducted in 1977 (Wren et al., 1980) and again in 1989 (Wren et al., 1994) on the emphasis of theory versus application among management educators. Using a sample of 525 members of the Academy of Management, they reported that the 1970s were a decade of theory but the 1980s were a decade of application. It is surprising then that their most recent research (2005 data) saw a trend reversal back to the theory. Wren et al. (2007) discussed:

In many instances, the 2005 respondents indicated that theory was even more pervasive in our pedagogy than was reported in the 1977 data . . Although theory is emphasized more in undergraduate courses, the aforementioned trend toward more theory is similarly occurring in graduate courses. This lends further credibility to the notion that theories are emphasized to a greater extent than the usefulness of those theories in practice at all levels of our management instruction. As some have suggested, it appears as though the trend in our pedagogy has been more directed toward the exercise of theory and analysis than toward training our students in thinking, analysis, and application skills. (p. 490) 
The debate for us is not surprising given that entrepreneurship is one of the most applied of all business disciplines, and many argue, us included, that, in order to learn entrepreneurship, one must $d o$ entrepreneurship. Our position, however, is that doing entrepreneurship does not exclude theory. On the contrary, effective doing of entrepreneurship requires a set of practices and these practices are firmly grounded in theory. The students, however, do not see the theory - it is invisible and hidden in the practice. We call this actionable theory (Neck and Greene, 2011; Corbett and Katz, 2012).

The poles of the continuum can be considered to be, on one side, the theory-based faculty member, perhaps with no "real" entrepreneurship experience, and guided by a belief and commitment to promulgating frameworks with a sincere belief that they will guide practice (e.g. the business plan) and, on the other end, the practitioner with a visceral disdain for what is perceived to be an ivory tower approach. The desired end advanced in this book is a synthesis. The matrix in Figure 1.1 is a useful guide to considering the theoretical-based options (or lack thereof) for teaching entrepreneurship today.

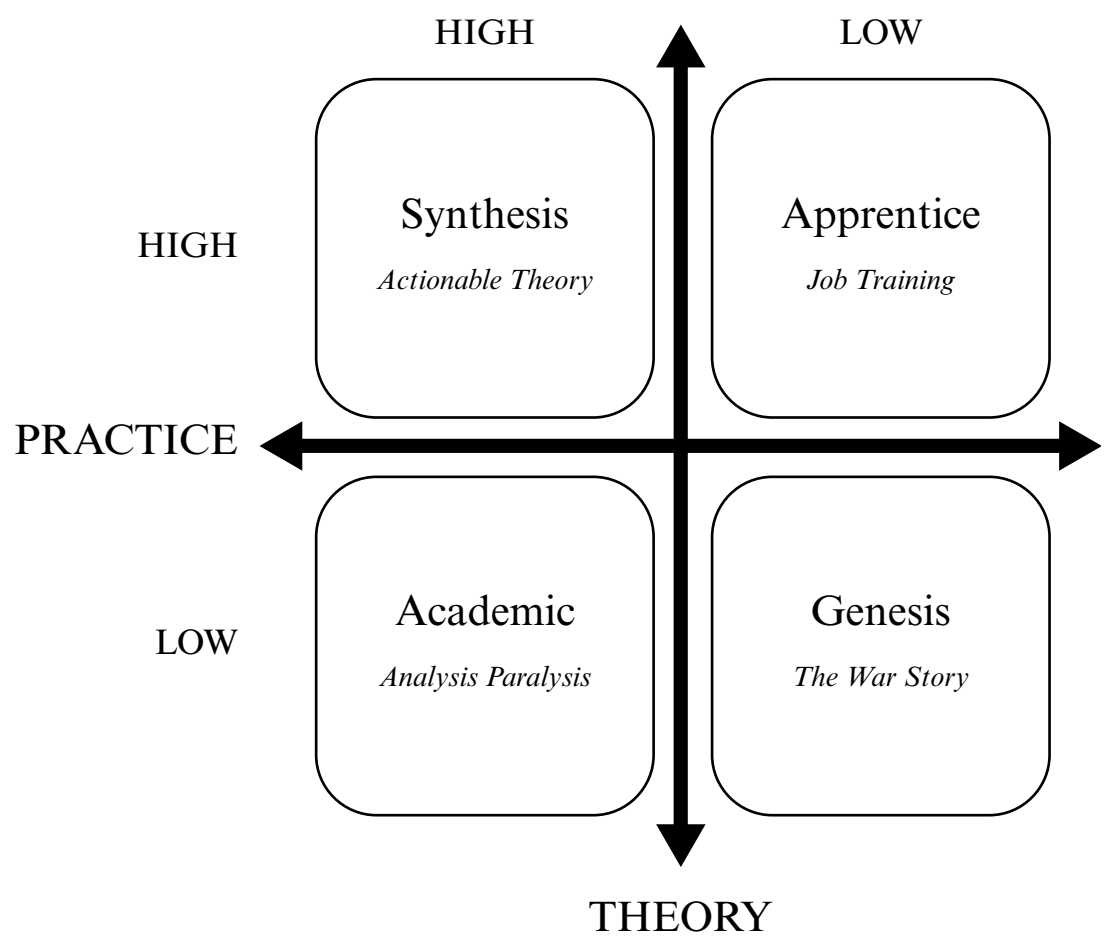

Figure 1.1 Theory-practice matrix 
Entrepreneurship education was born in Genesis. We had no research, no theory, and, therefore, very few options for teaching entrepreneurship except hearing the war stories. One of our favorite stories comes from the late Jeff Timmons (1941-2008):

\begin{abstract}
One of the challenges faced by faculty with real world experience is whether and how to utilize those experiences in the classroom. There are basically two schools of thought on this subject: 1) "Tell"; and (2) "Whatever you do, do not tell war stories." As you would guess these two groups are not seen frequently together in the faculty dining area. In fact, the entrepreneurs and business people are often admonished in advance by some regular faculty with a severe warning: no war stories. However, one must put this advice in perspective. Donald Brown, a highly successful real estate entrepreneur from Washington, DC, spent many years teaching one semester each year at HBS. Students considered him to be a highly effective professor. His insight on the advice of sage regular faculty colleagues at HBS "to avoid telling war stories" is priceless: "I finally figured out," Don noted in his talk, "that they did not have any war stories to tell!"4
\end{abstract}

Timmons had a point, and in 1984 he brought practitioners together with academics to solve the either/or issue and learn together the most effective ways at the time to teach entrepreneurship. The Price-Babson Symposium for Entrepreneurship Educators was born and continues today. However, today's entrepreneurship professor often has both entrepreneurial experience and academic experience - it is more the norm than the exception. We call it Genesis now because it represents the beginning of entrepreneurship education when war stories were really all we had. There is a limit to learning from war stories and very little practice is involved - we can say the same to some extent about case studies.

The Apprentice cell represents training of very specific tasks. It is a vocational perspective where skill development takes precedence over critical thinking and where understanding and developing theory is not important. The Academic cell supports theory but at the expense of action (e.g. the business plan), while the Synthesis cell provides the opportunity for informed application. Our book, and the practices that are highlighted, is devoted to a deep dive into the Synthesis cell - where invisible theory meets practice. Here we introduce a practice-based approach for teaching entrepreneurship. Let us not forget the famous words of Kurt Lewin, "There is nothing so practical as a good theory."

\title{
ENTREPRENEURSHIP AS A METHOD
}

We support entrepreneurship as a method because process implies one will get to a desired outcome if prescribed steps are followed. Furthermore, the 
word "process" assumes known inputs and known outputs as in a manufacturing process. In writing about this previously we used a car manufacturing analogy (Neck and Greene, 2011). Think about building a car on an assembly line. Great thought and engineering are involved in designing the process, where the required parts that enter the manufacturing process are known, the specifications of how the parts are to be assembled, and what the car will look like (exactly) as it comes off the line. The process is quite predictable. Can we really expect entrepreneurship to be such a process? Is entrepreneurship really that predictable? As we previously addressed, educators have traditionally accepted a process view - a view dominated by a linear, staged approach to new venture creation: identify an opportunity, develop the concept, determine resource requirements, acquire resources, develop a business plan, implement the plan, manage the venture, and exit (Morris, 1998).

Entrepreneurial environments are unpredictable, uncertain, and ambiguous, and require a specific mindset, which is in stark contrast to the environments we teach in. A method of entrepreneurship allows our students to navigate the discipline. A method represents a body of skills or techniques that help students develop a set of practices that implore them to think and act more entrepreneurially. We believe that introducing entrepreneurship as a method of practices is just as important as, if not more important than, the content so often seen in the textbooks. As we mentioned earlier, information is a commodity today; therefore, "we need to teach methods that stand the test of dramatic changes in content and context" (Neck and Greene, 2011, p. 62).

Approaching entrepreneurship as a method means teaching a way of thinking and acting built on a set of assumptions using a portfolio of practices to encourage creating. The method forces students to go beyond understanding, knowing, and talking. It requires using, applying, and acting. The method requires continuous practice. Therefore, our underlying assumptions of the method include (Neck and Greene, 2011, p. 62):

1. It applies to novices and experts: the assumption is that the method applies across student populations and works regardless of experience level. What is important is that each student understands how he or she views the entrepreneurial world and his or her place in it.

2. The method is inclusive, meaning that the definition of entrepreneurship is expanded to include any organization at multiple levels of analysis. Therefore, success is idiosyncratic and multidimensional.

3. The method requires continuous practice. The focus here is on doing and then learning, rather than learning and then doing.

4. The method is for an unpredictable environment. 


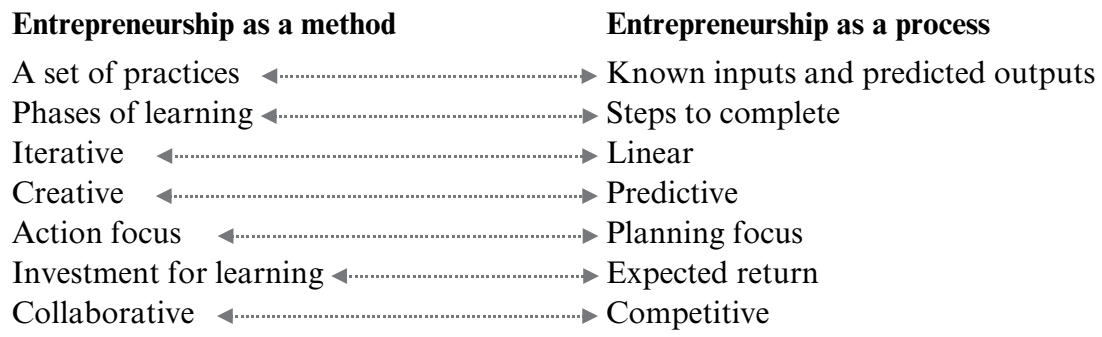

Source: Adapted from Neck and Greene (2011).

\section{Figure 1.2 Method versus process}

Figure 1.2 contrasts teaching entrepreneurship as a method and as a process. As we show in this book, the method view requires a different approach to teaching and learning. The method view is not about a class, a course, or even an entrepreneurship curriculum. Our view is concerned with inculcating a spirit of entrepreneurial thinking and acting into every student so that students may create their future regardless of context.

\section{THE FIVE PRACTICES OF ENTREPRENEURSHIP EDUCATION}

Billett (2010) in a robust, edited volume delves into practice theory and how learning through practice is operationalized (or not) in education settings. Practice-based learning is often seen as the stepchild living next door to the ivory tower. Billett (2010) notes that experiences from practice are "seen as adjunct to an educational provision that is organized and structured in colleges or universities or through programs offered by professional bodies and other agencies, rather than [learning] experiences that are both legitimate and effective in their own right" (p. 21). Within the realm of practice theory, practice is defined as "the enactment of the kinds of activities and interactions that constitutes the occupation" (Billett, 2010, p. 22). There is a long tradition of research that supports learning through practice. Because of the philosophical foundations of practice, we would be remiss to ignore Aristotle, who said: "For the things we have to learn before we can do them, we learn by doing them." Given such a rich tradition Billett (2010) notes that there is nothing new about learning from practice, but he is surprised that learning through practice is positioned in contrast to the traditional educational experiences offered in higher education (Rogoff and Gauvain, 1984). 
We are promoting the practice-based approach as a model of learning to support entrepreneurial action. Unlike the Apprentice cell (Figure 1.1), we are not promoting the pure practice models that ensure competence in a specialized occupation such as medicine, law, or even a position in a symphony orchestra. On the contrary, our goal is focusing on synthesis that encourages the practice of actionable theory. Rather than a narrow view of learning through practice which requires particular knowledge to enact the practice, we align with a broader perspective:

[Learning] can be enhanced by particular kinds of pedagogic activities which, as instanced, required the practitioner to represent their tacit learning in some way. This requirement creates an imbedded practice that has significant pedagogic qualities in so far as it generates the kinds of knowledge structures that make explicit what was tacit, and generates richer understanding about practice, but from and through practice, not on behalf of it. (Billett, 2010, p. 29)

A noted criticism of practice theorists is that they often treat practice as a singular and distinct construct while overlooking the complexity, diversity, and range of practice (Dall'Alba and Sandberg, 2010). This is precisely why we cannot simply say that entrepreneurship is a practice and must submit that entrepreneurship is a method composed of a portfolio of practices. In addition to learning through practice, we leave room for learning about practice. Both contribute to skillful performance (Dall'Alba and Sandberg, 2010).

The complexity of practice theory cannot be overstated, and our book cannot give justification to its rich history in the social sciences, especially in the fields of sociology and anthropology. Rouse (2006), analyzing the work of seminal practice theorists (e.g. Foucault, 1972; Bourdieu, 1977, [1980] 1990; Giddens, 1984; Pickering, 1992; Turner, 1994; Schatzki, 1996; Rouse 2002), identified several themes in practice theory that relate to our work and support entrepreneurship as a method or even metapractice. In other words, entrepreneurship is a set of practices that describe and give information about the method of entrepreneurship. Combined, our practices create a method of thinking and acting entrepreneurially.

1. Practices are meaningful performances governed by social rules and norms. Each practice highlighted in our book is governed by theory from multiple disciplines within and outside of business administration.

2. Practices become the background of culture formation and the platform for social structure construction. The practices of entrepreneurship discussed in the following chapters can create a culture of entrepreneurship among students, in classrooms and beyond. 
3. Practices are dependent on human agency and social interaction. Through sustained practice habits are formed that expand existing knowledge structures and encourage new ways of acting. Thus entrepreneurship is learned through practice.

4. Practices create shared meaning through "shared presuppositions, conceptual frameworks, vocabularies, or 'languages"” (Rouse, 2006, p. 515). Entrepreneurship education, through a practice-based approach, becomes a community of learning that is student-centered.

Just as we have been talking about what practice is, it is just as important to talk about what practice is not as it relates to our approach. An interesting line of inquiry emerging in the management and entrepreneurship literatures, but borrowed from cognitive science, is the concept of deliberate practice to achieve expert performance (Ericsson et al., 1993). Deliberate practice is devoting a large number of focused hours to intense practice to achieve mastery of a skill. For example, Chase and Simon (1973) studied chess players and estimated that mastery was achieved only after 10000 to 50000 hours of practice. More recently Campitelli and Gobet (2011) estimated that chess players need only 3000 hours of deliberate practice and found that other variables such as season of birth, cognitive ability, and being left-handed contributed to mastery. Deliberate practice has been applied to entrepreneurship as a way to show how some entrepreneurs outperform others. Baron and Henry (2010) proposed that expert performance resulting from deliberate practice could differentiate successful entrepreneurs from the less successful. They argued that deliberate practice by entrepreneurs could enhance cognitive resources while also increasing motivation, self-efficacy, and self-control. But a characteristic of deliberate practice is prolonged periods of highly focused practice such as those seen with chess players, athletes, and musicians. Baron and Henry (2010) admitted that prolonged periods of practice may not work for start-up entrepreneurs, nor is it clear what specific skills they would deliberately practice over and over.

To resolve this dilemma of extreme amounts of devoted time, Baron and Henry (2010) delve into the entrepreneurial learning literature. They introduce two types of learning: experiential learning and vicarious learning (Kolb and Kolb, 2005). For example, quarterbacks can learn while playing football (experiential learning) or they can learn by watching tapes of other quarterbacks (vicarious learning). Baron and Henry (2010) note:

Applying this general principle of vicarious learning to entrepreneurship, we suggest that an important route to building expert performance in situations where time pressures and other environmental conditions provide little oppor- 
tunity for hours of overt focused practice is offered by exposure to a large number of pertinent, realistic, and highly relevant examples. (p. 57)

The solution to the time dilemma required of deliberate practice, in our opinion, is not a solution at all. Rather, the approach offered by Baron and Henry is nothing new in entrepreneurship education - the use of examples and case studies as modes of vicarious learning - and is not moving entrepreneurship education forward. Students are relegated to the role of involved spectators (Higgins and Elliott, 2011). However, this does lead us to an important question related to the practice-based approach we are proposing. How does our practice-based approach differ from Kolb's popular notion of experiential learning?

Kolb (1984) defines experiential learning as knowledge created through the transformation of experience. He emphasizes a focus on the process of learning rather than outcomes of learning as well as the knowledge created and recreated through experiences. In other words, experiential learning emphasizes the experience, feedback from or interaction with others on the experience, and self-reflection on the experience (Kolb, 1984; Jennings and Wargnier, 2010).

Our practice-based approach complements that of Kolb and other experiential learning theorists. Our approach is mostly concerned with learning within the practice as well as learning through practice. Thus, the only way to learn within the practice is through experience. In each of our practices of entrepreneurship education learning, innovation, communication, interpretation, and history are present - the essential elements of experiential learning (Higgins and Elliott, 2011). In sum, the entrepreneurship method as a series of practices can only be learned through experiential approaches.

With an understanding of why we elect to view entrepreneurship as a method as well as a better understanding of what we mean by practice intertwined with the importance of theory, we can now turn to the core of our book - the practices subsumed in the method. Our concept of practice relates to the acquisition of skills, knowledge, and mindset through deliberate hands-on, action-based activities that enhance development of entrepreneurial competencies and performance. Given the complex and multifaceted nature of entrepreneurship, a single practice is not possible. Therefore, we introduce five specific practices of entrepreneurship education (Figure 1.3) that represent our earlier notion of synthesis (Figure 1.1) as the integration of theory and practice - actionable theory. The five practices include: the practice of play; the practice of empathy; the practice of creation; the practice of experimentation; and the practice of reflection. 


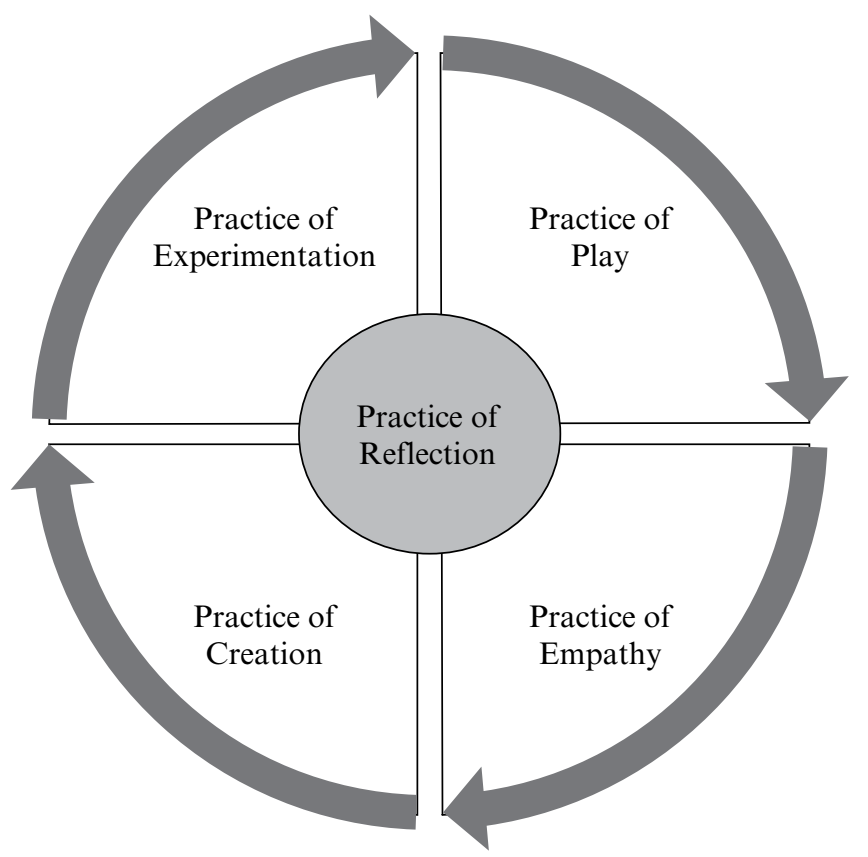

Figure 1.3 The practices of entrepreneurship education

\section{ORGANIZATION OF THE BOOK}

Our book is organized into two parts. Part I details the definitional and theoretical foundations for each of the practices. Chapter 2 introduces the practice of play. The practice of play relates to the development of a free and imaginative mind, allowing one to see a wealth of possibilities, a world of opportunities, and a pathway to more innovative ways of being entrepreneurial. Chapter 3 borrows heavily from psychology, neuroscience, and design thinking and introduces the practice of empathy. Empathy is defined as "a social and emotional skill that helps us feel and understand the emotions, circumstances, intentions, thoughts, and needs of others, such that we can offer sensitive, perceptive, and appropriate communications and support" (McLaren, 2013, p. 11). Chapter 4 introduces the practice of creation, which discusses the role of creativity in entrepreneurship education as well as delves into the world of creation in contrast to prediction. Chapter 5 characterizes the practice of experimentation, drawing from medical sociology and other theory. Experimentation is trying something, seeing what the results are, learning 
from the results, and then trying it again. Chapter 6 discusses our final practice - the practice of reflection. Reflection encourages students to codify their learning experiences, especially in high-action environments. This is perhaps the most integrating of all the practices, because there is evidence that practicing reflection can enhance each of the other practices (Schön, 1983).

Where Part I emphasizes the theoretical foundations of our practices, Part II includes a series of 42 experiential exercises, organized by practice, that can help students develop each of their entrepreneurship practices within a classroom environment. Chapters 7-11 include exercises related to play, empathy, creation, experimentation, and reflection respectively. Each exercise includes an extensive teaching note that describes the exercise, learning outcomes, classroom plan, summary points, readings for theoretical foundations, and teaching tips. Our focus on classroom activities is intentional. We recognize the importance, more now than ever, of co-curricular activities, but we also know how faculty struggle with engagement inside the classroom. Therefore, we are meeting a need of our colleagues to address practical engagement in the classroom based on rigorous (yet invisible) theory.

In concluding, Chapter 12 includes our final thoughts and addresses assessment. There is a popular myth that entrepreneurship education does not progress owing to the limitations and constraints demanded by accreditation. There is fear among faculty and administrators that using a practice-based approach will not meet the traditional assurance of learning standards mandated by AACSB and other accrediting bodies. We debunk the myths and fears and argue that a practice-based approach can be a viable pathway to meet the current standards required of business schools. How do we know this? Because we interviewed the President and CEO of AACSB, John Fernandes, and he told us so!

\section{NOTES}

1. Jeff Timmons (1941-2008) is considered one of the founding fathers of entrepreneurship education. A distinguished professor at Babson from 1982, Jeff played a central role in Babson College's status in entrepreneurship education. His commitment to higher education and to entrepreneurship was a statement of his belief in humanity. He believed goodness and achievement were inherent in everyone. Jeff also believed that entrepreneurship classes were a perfect vehicle to redefine and amplify purposeful study and action that would lead to a better life and a better world.

2. During the same time that the process approach was emerging, Aldrich (1990) and Aldrich and Wiedenmeyer (1993) introduced the "rates" approach grounded in the ecology of organization formation. "Rates" researchers focused on the environmental conditions generating variation in the number of foundings over time. The rates 
approach has great application to public policy but has not made its way into most entrepreneurship classrooms - or at least in a substantive way beyond the presentation of start-up, growth, and failure statistics.

3. See Sarasvathy (2008, pp . 19-43) for a detailed discussion on the rigor and efficacy of her research methodology.

4. This quote came from a note Jeff Timmons wrote for the Price-Babson SEE program titled "War Stories: To Tell or Not to Tell?" The date it was originally written is unknown.

\section{REFERENCES}

Aldrich, H.E. 1990. Using an ecological perspective to study organization founding rates. Entrepreneurship Theory and Practice, 14(3), 7-24.

Aldrich, H.E., and Cliff, J.E. 2003. The pervasive effects of family on entrepreneurship: Toward a family embeddedness perspective. Journal of Business Venturing, 18, 573-96.

Aldrich, H.E., and Wiedenmeyer, G. 1993. From traits to rates: An ecological perspective on organizational foundings. Advances in Entrepreneurship, Firm Emergence, and Growth, 1, 145-95.

Baron, R.A., and Henry, R.A. 2010. How entrepreneurs acquire the capacity to excel: Insights from research on expert performance. Strategic Entrepreneurship Journal, 4, 49-65.

Bastin, M. 2014. Entrepreneurship education needed in China. Forbes.com, http://www.ft.com/cms/s/2/80529984-876b-11e3-9c5c-00144feab7de. html\#axzz2sZuH2YYd.

Bennis, W., and O’Toole, J. 2005. How business schools lost their way. Harvard Business Review, 98(5), 96-104.

Billett, S. (ed.). 2010. Learning through Practice: Models, Traditions, Orientations and Approaches. London: Springer.

Bourdieu, P. 1977. Outline of a Theory of Practice. Cambridge, UK: Cambridge University Press.

Bourdieu, P. [1980] 1990. The Logic of Practice. Stanford, CA: Stanford University Press.

Brockbank, A., and McGill, I. 2007. Facilitating Reflective Learning in Higher Education, 2nd edn. New York: Open University Press.

Brockhaus, R.H. 1980. Risk taking propensity of entrepreneurs. Academy of Management Journal, 23(3), 509-20.

Brockhaus, R., and Horwitz, P. 1986. The psychology of the entrepreneur. In D. Sexton and R. Smilor (eds.), The Art and Science of Entrepreneurship (pp. 25-48). Cambridge, MA: Ballinger.

Brush, C.G., Greene, P.G., and Hart, M.M. 2001. From initial idea to unique competitive advantage: The entrepreneurial challenge of constructing a resource base. Academy of Management Executive, 15(1), 64-78.

Brush, C.B., Duhaime, I.M., Gartner, W.B., Stewart, A., Katz, J.A., Hitt, M.A., Alvarez, S.A., Meyer, G.D., and Venkataraman, S. 2003. Doctoral education in the field of entrepreneurship. Journal of Management, 29(3), 309-31.

Bygrave, W.D., and Hofer, C.W. 1991. Theorizing about entrepreneurship. Entrepreneurship Theory and Practice, 16(2), 13-22. 
Campitelli, G., and Gobet, F. 2011. Deliberate practice: Necessary but not sufficient. Current Directions in Psychological Science, 20(5), 280-85.

Chase, W.G., and Simon, H.A. 1973. Perceptions in chess. Cognitive Psychology, 4, 55-81.

Collins, O.F., and Moore, D.G. 1970. The Organization Makers. New York: Appleton-Century-Crofts.

Cooper, A.C., and Dunkelberg, W.C. 1981. A new look at business entry: Experiences of 1805 entrepreneurs. In K.H. Vesper (ed.), Frontiers of Entrepreneurship Research. Wellesley, MA: Babson College.

Corbett, A.C., and Katz, J.A. (eds.). 2012. Advances in Entrepreneurship, Firm Emergence and Growth, Vol. 14: Entrepreneurial Action. Bingley, UK: Emerald Group Publishing.

Costello, C., Neck, H., and Williams, R. 2011. Elements of the Entrepreneur Experience. Babson Park, MA: Babson Entrepreneur Experience Lab.

Dall'Alba, G., and Sandberg, J. 2010. Learning through and about practice: A lifeworld perspective. In S. Billett (ed.), Learning through Practice: Models, Traditions, Orientations and Approaches (pp. 143-62). London: Springer.

Datar, S.M., Garvin, D.A., and Cullen, P. 2010. Rethinking the MBA: Business Education at the Crossroads. Boston, MA: Harvard Business Press.

DeCarlo, J.F., and Lyons, P.R. 1979. A comparison of selected personal characteristics of minority and non-minority female entrepreneurs. Journal of Small Business Management, 17, 22-9.

Drucker, P. 1985. Innovation and Entrepreneurship. New York: Harper \& Row.

Edelman, L.F., Manolova, T.S., and Brush, C.B. 2008. Entrepreneurship education: Correspondence between practices of nascent entrepreneurs and textbook prescriptions for success. Academy of Management Learning and Education, 7(1), 56-70.

Ericsson, K.A., Krampe, R.T., and Tesch-Römer, C. 1993. The role of deliberate practice in the acquisition of expert performance. Psychological Review, 100, 363-406.

Fisher, J.L., and Koch, J.V. 2008. Born Not Made: The Entrepreneurial Personality. Westport, CT: Praeger.

Foucault, M. 1972. The Archeology of Knowledge. New York: Harper \& Row.

Gartner, W.B. 1988. Who is an entrepreneur? is the wrong question. American Journal of Small Business, 12(4), 11-32.

Giddens, A. 1984. The Constitution of Society. Berkeley: University of California Press.

Greenberg, D., McKone-Sweet, K., and Wilson, H.J. (eds.). 2011. The New Entrepreneurial Leader: Developing Leaders Who Will Shape Social and Economic Opportunities. San Francisco: Berrett-Koehler.

Greene, P.G. 1993. A theoretical and empirical study of self-employed women. Dissertation, University of Texas at Austin.

Higgins, D., and Elliott, C. 2011. Learning to make sense: What works in entrepreneurial education? Journal of European Industrial Training, 35(4), 345-67.

Hitt, M.A., Ireland, R.D., Camp, M., and Sexton, D.L. 2001a. Integrating entrepreneurship and strategic management actions to create firm wealth. Academy of Management Perspectives, 15(1), 49-63.

Hitt, M.A., Ireland, R.D., Camp, M., and Sexton, D.L. 2001b. Strategic entrepreneurship: Entrepreneurial strategies for wealth creation. Strategic Management Journal, 22(6-7), 479-91. 
Jennings, C., and Wargnier, J. 2010. Experiential learning: A way to develop agile minds in the knowledge economy? Development and Learning in Organizations, 24(3), 14-16.

Katz, J. 2003. The chronology and intellectual trajectory of American entrepreneurship education 1876-1999. Journal of Business Venturing, 18(2), 283-300.

Kolb, A.Y., and Kolb, D.A. 2005. Learning styles and learning spaces: Enhancing experiential learning in higher education. Academy of Management Learning and Development, 4(2), 193-212.

Kolb, D.A. 1984. Experiential Learning: Experience as the Source of Learning and Development. Englewood Cliffs, NJ: Prentice Hall.

Kuratko, D.F. 2005. The emergence of entrepreneurship education: Development, trends, and challenges. Entrepreneurship Theory and Practice, 29(5), 577-97.

Krueger, N.R. 2007. What lies beneath? The experiential essence of entrepreneurial thinking. Entrepreneurship Theory and Practice, 31(1), 123-38.

Low, M.B., and MacMillan, I.C. 1988. Entrepreneurship: Past research and future challenges. Journal of Management, 14(2), 139-61.

MBA Roundtable. 2012. Curricular Innovation Study, http://www.mbaroundtable. org/curricular_innovation_study.

McClelland, D. 1965. Need achievement and entrepreneurship: A longitudinal study. Journal of Personality and Social Psychology, 1, 389-92.

McLaren, K. 2013. The Art of Empathy: A Complete Guide to Life's Most Essential Skill. Boulder, CO: Sounds True.

Meyer, G.D., Neck, H.M., and Meeks, M. 2002. The entrepreneurshipstrategic management interface. In M.A. Hitt and D. Ireland (eds.), Strategic Entrepreneurship (pp. 19-44). Oxford, UK: Blackwell.

Miner, J.B. 1996. The 4 Routes to Entrepreneurial Success. San Francisco: Berrett-Koehler.

Mintzberg, H. 2004. Managers, Not MBAs: A Hard Look at the Soft Practices of Managing and Management Development. San Francisco: Berrett-Koehler.

Mitchell, R.K., Smith, J.B., Seawright, K.W., and Morse, E.A. 2000. Crosscultural cognitions and the venture creation decision. Academy of Management Journal, 53(5), 974-93.

Mitchell, R.K., Busenitz, L., Lant, T., McDougall, P., Morse, E.A., and Smith, B. 2002. Toward a theory of entrepreneurial cognition: Rethinking the people side of entrepreneurship research. Entrepreneurship Theory and Practice, 27(2), 93-104.

Morris, M.H. 1998. Entrepreneurial Intensity: Sustainable Advantages for Individuals, Organizations, and Societies. Westport, CT: Quorum.

Mount, I. 2010. Nature vs. nurture: Are great entrepreneurs born . . . or made? Fortune Small Business, December 09/January 10, 25-6.

Myrah, K., and Currie, R. 2006. Examining undergraduate entrepreneurship education. Journal of Small Business and Entrepreneurship, 19(3), 233-53.

Neck, H.M., and Greene, P.G. 2011. Entrepreneurship education: Known worlds and new frontiers. Journal of Small Business Management, 49(1), 55-70.

Noyes, E., and Brush, C. 2012. Teaching entrepreneurial action: Application of creative logic. In A.C. Corbett and J.A. Katz (eds.), Entrepreneurial Action: Advances in Entrepreneurship and Firm Emergence and Growth (pp.253-80). Bingley, UK: Emerald Group Publishing.

Pickering, A. 1992. Science as Practice and Culture. Chicago: University of Chicago Press. 
Rogoff, B., and Gauvain, M. 1984. The cognitive consequences of specific experiences: Weaving versus schooling among the Navajo. Journal of Cross-Cultural Psychology, 15(4), 453-75.

Rouse, J. 2002. How Scientific Practices Matter: Reclaiming Philosophical Naturalism. Chicago: University of Chicago Press.

Rouse, J. 2006. Practice theory. In Handbook of the Philosophy of Science, Vol. 15: Philosophy of Anthropology and Sociology, ed. Stephen Turner and Mark Risjord (pp. 499-540). Amsterdam: North-Holland.

Ryle, G. 1967. Teaching and training in education. In R.S. Peters (ed.), The Concept of Education. London: Routledge \& Kegan Paul.

Ryle, G. 1983. The Concept of Mind. Harmondsworth: Penguin.

Sarasvathy, S.D. 2001. Causation and effectuation: Toward a theoretical shift from economic inevitability to entrepreneurial contingency. Academy of Management Review, 26(2), 243-63.

Sarasvathy, S.D. 2003. Entrepreneurship as a science of the artificial. Journal of Economic Psychology, 24, 203-20.

Sarasvathy, S.D. 2008. Effectuation: Elements of Entrepreneurial Expertise. Cheltenham, UK and Northampton, MA, USA: Edward Elgar Publishing.

Schatzki, T. 1996. Social Practices: A Wittgensteinian Approach to Human Activity and the Social. Cambridge, UK: Cambridge University Press.

Schlesinger, L., Kiefer, C., and Brown, P. 2012. Just Start: Take Action, Embrace Uncertainty, Create the Future. Cambridge, MA: Harvard Business School Press.

Schön, D. 1983. The Reflective Practitioner: How Professionals Think in Action. New York: Basic Books.

Shane, S. 2012. Reflections on the 2010 AMR decade award: Delivering on the promise of entrepreneurship as a field of research. Academy of Management Review, 37(1), 10-20.

Shane, S., and Venkataraman, S. 2000. The promise of entrepreneurship as a field of research. Academy of Management Review, 25(1), 217-26.

Trank, C.Q., and Rynes, S.L. 2003. Who moved our cheese? Reclaiming professionalism in business education. Academy of Management Learning and Education, 2(2), 189-205.

Turner, S. 1994. The Social Theory of Practices: Tradition, Tacit Knowledge, and Presuppositions. Chicago: University of Chicago Press.

Venkataraman, S. 1997. The distinctive domain of entrepreneurship research. Advances in Entrepreneurship, Firm Emergence and Growth, 3, 119-38.

Venkataraman, S., Sarasvathy, S.D., Dew, N., and Forster, W.R. 2012. Reflection on the 2010 AMR decade award: Whither the promise? Moving forward with entrepreneurship as a science of the artificial. Academy of Management Review, $37(1), 21-33$.

Vesper, K.H., and Gartner, W.B. 1997. Measuring progress in entrepreneurship education. Journal of Business Venturing, 12(5), 403-21.

Wren, D.A., Atherton, R.M., and Michaelsen, L.K. 1980. Theory and applications in management pedagogy: An empirical study. Journal of Management, 6(1), 21-31.

Wren, D.A., Buckley, M.R., and Michaelsen, L.K. 1994. The theory/applications balance in management pedagogy: Where do we stand? Journal of Management, 20(1), 141-57.

Wren, D.A., Halbesleben, J.R.B., and Buckley, M.R. 2007. The theory- 
application balance in management pedagogy: A longitudinal update. Academy of Management Learning and Education, 6(4), 484-92.

Xavier, S.R., Kelley, D., Kew, J., Herrington, M., and Vorderwülbecke, A. 2012. Global Entrepreneurship Monitor: 2012 Global Report. Global Entrepreneurship Research Association, www.gemconsortium.org.

Zahra, S., and Dess, G.C. 2001. Entrepreneurship as a field of research: Encouraging dialogue and debate. Academy of Management Review, 26(1), 8-10. 